\title{
The order of the mission and action games: conflicts, strategies and traps in Amazon in the $17^{\text {th }}$ century ${ }^{I}$
}

\author{
Almir Diniz de Carvalho Júnior[1]
}

\begin{abstract}
During the $17^{\text {th }}$ century, the spiritual and political conquest process of the Amazon Amerindian populations was led by the Portuguese Crown and catholic missionaries. These missionaries were divided into many religious groups and were under Jesuits' main control. This article is about the political strategies of Christian Indians, at the time of the catholic missions, analysed through a singular episode which involved the Jesuit Antônio Vieira and the Principal Indian Lopo de Souza in the middle of the $17^{\text {th }}$ century. The purpose is to bring out the complex political relationship, the surviving and fighting strategies for autonomy spaces from the Indians, who were placed between vassal order and slavery.
\end{abstract}

Keywords: indian history; Amazon colonial history; cultural history.

\section{A ordem da missão e os jogos da ação: conflitos, estratégias e armadilhas na Amazônia do século XVII}

\section{Resumo}

Durante o século XVII, o processo de conquista espiritual e política das populações ameríndias na Amazônia foi conduzido pela Coroa Portuguesa e pelos missionários católicos divididos em várias ordens religiosas e sob a gerência dos Jesuítas. Este artigo aborda as estratégias políticas dos índios cristãos, no tempo dessas missões, a partir de um singular episódio que envolveu o jesuíta Antônio Vieira e o Principal indígena Lopo de Souza em meados do séculoXVII. O objetivo é revelar as complexas relações políticas e as estratégias de sobrevivência e de luta por espaços de autonomia desses índios, situados entre a vassalagem e a escravidão.

Palavras-chave: história indígena; história colonial da Amazônia; história cultural.

\section{La orden de misión y los juegos de acción: conflictos, estrategias y armadillas en la Amazonia del siglo XVII}

\section{Resumen}

En el siglo XVII, el proceso de conquista espiritual y política de las populaciones amerindias en la Amazonia fue conducido por la Corona Portuguesa y por los misionarios católicos, divididos en diversas órdenes religiosas y con la gerencia de los Jesuitas. Esto artículo aborda sobre las estrategias políticas de los indios cristianos en el momento de las misiones desde un único episodio que envolvió el jesuita Antônio Vieira y el Principal indígena Lopo de Souza durante el siglo XVII. El objetivo fue revelar las complejas relaciones políticas y las estrategias de sobrevivencia y de lucha por los espacios de autonomía de esos indios, situados entre la vasallaje y la esclavitud.

Palabras-clave: historia indígena; historia colonial de Amazonia; historia cultural.

\section{L'ordre de la mission et des jeux d'action: les conflits, les stratégies et les pièges de l'Amazonie au XVIIle siècle}

\section{Résumé}

Tout au long du XVIIe siècle, le processus de conquête spirituelle et politique des populations amérindiennes fut mené par la monarchie portugaise et par les missionnaires catholiques,divisés en divers ordres religieux, sous la gestion des Jésuites. Cet article examine les stratégies politiques des Indiens chrétiens à partir d'un épisode singulier qui concerna le Jésuite Antônio Vieira et le Principal Indien, Lopo de Souza, vers la fin de la première moitié du XVIIe siècle. Le but en est de dévoiler les rapports politiques complexes et les stratégies de lutte et de survie de ces Indiens, placés entre la vassalité et l'esclavage, pour conquérir des espaces d'autonomie.

Mots-clés: histoire des indiens; histoire coloniale de Amazonie; histoire culturel. 
$\mathrm{T}$ he conquest of the Amazon by the Portuguese involved wars, alliances, religious conversions and negotiations. In the early $17^{\text {th }}$ century, the Portuguese arrived in the region. After expelling the French from Maranhão, they took part in many other confrontations. ${ }^{2}$ They fought against the English, the Irish and the Dutch during the first half of the $17^{\text {th }}$ century. At the same time, they had a struggle against the Tupinambás of Maranhão who were allied with the Tupinambás of Pará, and inflicted four years of fight. ${ }^{3}$

This article dwells on the beginning of the attempt for a deeper conquest. The interior conflicts through religion were always followed by political conquest. Portuguese and the indigenous people began a complex political game since they came in contact first. Portuguese strategists, little by little, realized that the indigenous population knew about innovative war techniques and shared a sophisticated system of alliances. Depending on the type of deal or alliance established with them, these populations could get the military support of a different European nation. Fidelity was gained with good negotiations followed by interesting advantages. ${ }^{4}$ The political agency was essential for the conversion of the indigenous population into Christianity. Without the alliances with these populations, or the game of mutual interests played and the speeches of protecting missionaries, it was likely that not even one native would have embraced the new religion. In the game of conquest, the Amazon natives also had a leading role; they were not helpless victims. They negotiated and survived by creating spaces of relative autonomy.

This narrow autonomy, however, did not exist without violence. Violence has always been an essential ingredient in the system of control and domination. It is important to remember that the process of transforming traditional indigenous communities was not easy. The Portuguese had to put into practice their domination by overcoming the relations between the whites and the natives. This ended up in fights in the material field and, maybe more dramatically, in the spiritual and cultural fields.

This article analyzes the attempt of spiritual domain that was formed during the political conquest. Amazon was then divided into several religious orders in the attempt to fulfill the essential objective of the Portuguese conquest mission: to gather useful vassals and new 'souls to God'. Among these orders, the Society of Jesus prevailed. Its members were leading actors in this story. However, in the scene to be described ahead, the main characters were

\footnotetext{
In 1621, king Phillip IV created the State of Maranhão apart from the State of Brazil. It comprehended all of the North, part of the Northeast and part of the Center-West of the current Brazilian territory.

${ }^{3}$ Almir Diniz de Carvalho Júnior, de. Indios Cristãos - a conversão dos gentios na Amazônia Portuguesa (16531769), Tese de Doutorado, Unicamp, Campinas, 2005, p. 39-83.

${ }^{4}$ About the complexity of negotiation processes between Europeans and natives, see: Ronaldo Vainfas, Traiçãoum jesuíta a serviço do Brasil holandês processado pela inquisição, São Paulo, Companhia das Letras, 2008, especially the chapter "Imbróglio indígena". The author analyzes the drama of the former Jesuit, allied to the Dutch, and, afterwards, essential key for the reconquest of Pernambuco by the Portuguese - Manoel de Moraes. In this chapter, the author demonstrates the importance of the alliance between potiguaras and the Dutch, revealing some indigenous characters who participated in this war.
} 
not simply these men in cassocks or the colonial administrators alone. On this stage, the Christian Indians were also important. ${ }^{5}$

\section{Religious orders in Portuguese Amazon}

The Franciscans of the province of Santo Antônio were the first ones to arrive at the Amazon world. Afterwards came the missionaries of the Society of Jesus. With time, the Carmelite and the Mercedarian orders arrived. Other provinces of Franciscans also reached the Amazon ground:Capuchos da Piedade(Franciscans known as 'mercy capuchins') and, finally, the Friars of Conceição da Beira e Minho. The Portuguese State financed them, and in return, the orders had to catechize the pagans and provide intellectual and spiritual assistance to the colonists. ${ }^{6}$

The obligations to convert the pagans were not restricted to the spiritual field. Deep behavioral changes were part of the conversion program, such as: eradication of their nomadic habits; technical preparation/training to work with mechanical instruments; changes in the spatial organization of their old tribal system, turning the area into urban centers; creation of a disciplined work regime, based on agriculture; and finally, changes in their social lifestyle, creating the structure and the bonds of a Christian family. The major objective of this "conversion project" was to transform them into useful vassals and Christians. ${ }^{7}$

According to Ferreira Reis, the need to establish missions in the Amazon was also due to the fear of the Portuguese Crown in relation to the influence and domain of the French Calvinists and the English, the Dutch and the Irish reformers who were located along the east-west coast, that were jeopardizing the commercial and political interests of the Portuguese in the region. Their greatest fear was the relationships that the other nations began to establish with native populations, teaching them other spiritual guidelines. For these reasons and a few others, the support from missionary orders was essential for achieving the definitive domination and control of that native group by the first conquerors of the region. ${ }^{8}$

To accomplish this task, the first religious orders that arrived in the region were given the powers of a temporal government of those indigenous populations. According to the missionaries, it would have been extremely difficult to conduct their missions without such an authority, even though this concession

\footnotetext{
"Christian Indians" were in a generic identity key, but a very specific one. They defined the limits of such identification concretely. Only those who were baptized could be "Christians", and only "natives" could fit in this category. There were several ethnicities in its origin, but they defined a particular type of social insertion. The appropriation of this identify led to the innovative response that the native populations gave to the colonization project. It was a way for them to take over their destinies. Being a Christian, before being a generic definition, was a choice - result of their agency. See: Almir Diniz de Carvalho Júnior, Indios Cristãos - a conversão dos gentios na Amazônia Portuguesa (1653-1769), Tese de Doutorado, Unicamp, Campinas, 2005. ${ }^{6}$ Franciscans were not the first ones to arrive in Maranhão, where Jesuits came before them. See: Carlos Araújo Moreira Neto, "Os principais grupos missionários que atuaram na Amazônia brasileira entre 1607 e 1759", In: Eduardo Hoornaert (org.), História da Igreja na Amazônia, Petrópolis, Vozes, 1992, p. 65-66. 7ldem, Ibidem, p. 8.

${ }^{8}$ Arthur Cezar Ferreira Reis, A Conquista Espiritual da Amazônia, 2. Ed., Manaus, EDUA/Governo do Estado do Amazonas, 1997, p. 2-6
} 
had its setbacks. The participation of religious orders in the temporal domain of its new catechumens prevailed with prospects of conflicts among the varied interests of other parts of the colonial population in the region. They, at times, acquired the concession of the temporal right to themselves.

\section{Vieira stated the special aspect of his Society in comparison to the other orders in the Amazon. At that time, Jesuits had been expelled from the state of Maranhão}

Franciscans, Mercedarians, Carmelites and the ramifications of their activities in the space played an important role in the balance of interests that were divided between the Crown and the residents. The Portuguese Crown also had to keep the geopolitical control over the region, and turned it into an important commercial center for the riches of the empire. On the other hand, the economic interests of the residents sometimes conflicted with the need to maintain the allied natives, transforming them into loyal vassals. The missionaries provided essential services for both the groups. However, these aforementioned orders were easily submissive to local interests, and their institutional fragility was visible when compared to the soldiers of Christ, the Society of Jesus. The latter, unlike the former, served the Crown with more "fidelity" and, at the same time, met its own institutional interests.

\section{Jesuits - the Stars of Christ}

From these soldiers of Christ, the one who was deeply involved with the foundation of the Order in the Amazon was Father Antônio Vieira. This beautiful text emphasizing the particularities of the institution is his, of which he was the best herald. He talked from the pulpit of the royal chapel, in Lisbon, on January 6, 1662, and his most illustrious listener was the Queen, Luisa - back then, the ruler of the empire, due to the recent death of King John IV, who was a good friend and protector of Vieira. He referred to the recent expulsion he had suffered in Maranhão. In this piece, he mentions the star that guided the three wise men to meet the newly born Jesus:

What was the role of that Star? To brighten, guide and bring men to adore Christ, and no other men but those unfaithful and idolaters, born and raised in the darkness of Paganism. For this is the role and exercise not only of any Preacher, but of those Preachers we talk about, and that is why they are the Stars of Christ [...] Are not all of the other Stars, also, Stars of Christ, since God created them? Yes, they are. So why is this star, more than the others, specially called your Star: Stella ejus? Because the other stars 
were usually created to lighten Heaven and the world; this one was especially created to be the Preacher of Christ [...]. There are many other Stars in that Hemisphere, very bright in resplendence and very useful in influences, such as the ones in Heaven; but the ones we talk about specially belong to Christ, not only by the name of Jesus, with which they claim to be his; but because the purpose, the institute, and the role for which they were created is the same as the Star of the Wise Men, to bring the unfaithful and the pagans to the Faith in Christ. ${ }^{9}$

With his specific knowledge, Vieira stated the special aspect of his Society in comparison to the other orders in the Amazon. At that time, Jesuits had been expelled from the state of Maranhão. It was the end of the first period of this order which had been working in that land. Not by chance, the other orders were also called by local authorities to be established in the Amazon, and it was also not an accident that Jesuits were expelled twice, in 1661 and in 1684. In the early years of the mission, the conflicting interests between the objectives of the Society of Jesus, the residents and the colonial authorities were very clear. Consequently, since it was not possible to dispense with the missionaries in the process to dominate the indigenous population, the colonial authorities established closer relationships with the other orders, imposing their interests and limiting their work.

It is true that the role of Vieira worsened this situation involving conflicts of interests. He founded the mission in Maranhão and Pará, and he felt very deeply about it. He abandoned the favors of the court to be part of this mission, which he knew was going to be difficult. From the beginning, in 1653, to the year of 1661, Vieira had enviable power: friend and confident of the King, he was feared and respected. As a consequence, both in the court and in the colony, he made enemies. Besides, his rhetoric was a powerful weapon, which he was not afraid to use when it seemed necessary, astonishing his adversaries. It is even possible to follow the institution of the Jesuit mission in the Amazon by the rhythm of his sermons.

Arriving in São Luís, in 1653, he preached the Temptation Sermon, through which he spoke against the enslavement of the natives. After having initiated his first contact with the Amazon natives, he went to river Tocantins to establish the mission. When he returned to Maranhão, he preached the Saint Anthony's sermon to the fishermen. Through that, he attacked colonial authorities, using the image of aquatic inhabitants. This way, he assumed the character that would be his mark throughout his trajectory in that region - he would not temporize. In that sermon, he vehemently attacked unfair slavery. With this attitude, he made some powerful enemies in the colony, who would afterwards articulate the expulsion of the Order from those lands.

In those years, the power of Vieira was intact. Right after this sermon, he went to the Court, where he preached another sermon in the Royal Chapel: the

9Antônio Vieira, "Sermão da Epifania", In: Alcir Pécora (org.), Antônio Vieira - Sermões, Tomo I, São Paulo, Hedra, 2003, p. 605. 
preaching of the word of God. In this sermon, he pointed out to the difficulties of the mission in Maranhão. With his persuasive power, he got the support that was concretized in the law of April 9, 1655, concerning the freedom of the natives. He returned triumphantly to Maranhão and Pará, accompanied by the new governor, André Vidal de Negreiros, who was chosen by the King under his supervision. During the following six years, he tried to put his indoctrination process in practice. Vidal de Negreiros became his strongest ally, and, with his help, he achieved his objectives.

Between 1658 and 1660, he wrote Regulamento das Aldeias, known as "Vieira's visit". With this document, he established the guidelines for the mission in the Amazon. Such guidelines, with very few changes, remained in force for more than one century. This document brought up the routine of the missionary initiative more directly, involving the form of indoctrination and the disposition of the household space for missionaries and natives. Such rules should not only be followed by the Jesuits, but by all of the other orders. At the same time, the law of 1655 gave total primacy to the Society of Jesus in relation to the catechizing of the natives. ${ }^{10}$

After the Jesuits were expelled in 1661, in a final effort, Vieira preached another sermon, in which the aforementioned piece stood out, which came to be known as the "Sermon of the Amazon", formally called "Sermon for Epiphany". Queen Luisa was touched by the ideas of the orator; however, she could no longer help him. She was deposed, and Alfonso VI replaced her. Against the wishes of Vieira, the new King approved the law of September 12, 1663, repealing the law of 1655 , which took away the primacy of the Jesuits in relation to the temporal administration of the natives. With the new law, the Chambers (Municipal Council) of Belém and São Luís began to control the administration.

Vieira fell in disgrace and was arrested by the court of Inquisition. He was in prison from 1663 to 1667 . But, even though he was defeated at that time, he came back to action. He could not go back to Maranhão, but from a distance he still influenced the law of April $1^{\text {st }}, 1680$, which provided the freedom for the natives, and that was also favorable to the Jesuits. The consequence of this law was also a conflict that took place in 1684, culminating in another expulsion of the priests of the Society. After the rebellion of 1684, known as the "Beckman Revolt", a new law was established - and this one would last. It was the "Regiment of the Missions of the States of Maranhão and Grão-Pará", which was promulgated on December $21^{\text {st }}, 1686$. The regiment started a new life in the religious missions of the Amazon, and a new

${ }^{10}$ About "Regulamento das Missões", see: Almir Diniz de Carvalho Júnior, "A Doutrinação dos Gentios", In: Indios Cristãos - a conversão dos gentios na Amazônia Portuguesa (1653-1769), Tese de Doutorado, Unicamp, Campinas, 2005, p. 158-171. 
beginning for the Society of Jesus. The influence of Vieira lost its strength and pragmatism took place. ${ }^{11}$

The intentions of Vieira to transform the Society of Jesus into the "guiding star" were replaced by the circumstances of the missionary work in that region. The "Stars of Christ" lost their glow. Still, they remained shining, and guided, in a way, the other "stars" as they wished.

\section{The Jesuits and the control over the first missions}

Even though Jesuits had arrived at Maranhão in 1615, the effective control over the administration of the natives was only carried out with Vieira. Before that, their role was basically to catechize the villages they visited. Luiz Figueira started conversions in 1639. However, in 1643, he passed away along with other Jesuits in a shipwreck and became martyrs. ${ }^{12}$

It was not easy to put the mission into practice in the years to come. In 1649, new missionaries were also killed by the natives. It was only in 1652 that the mission finally began, with the arrival of other Jesuits sent by Antônio Vieira, who was then in charge of all the missions.

Vieira came right after, in 1653. He arrived in the same year of the publication of the Royal Order, led by the captain-major of Maranhão. With this order, which had the participation of the Jesuit, the captain set free all of the natives who had been enslaved. However, Antônio Vieira could feel the animosity that was prevalent among the residents in relation to the Society of Jesus, when he arrived. That is what he revealed in a letter to Bahia, referring to the new orders brought into force by the captain-major. He emphasized the public mutiny that occurred in the streets, in the Chamber, in the square. The conflict had weapons and a lot of confusion, the sentencing of Vieira, ironically, caused a revolution amongst the population: "[...] they had all decided to lose their lives (some even offered their souls) instead of agreeing to get expelled from their homes which they had bought for their money." ${ }^{13}$

Vieira says that the blazes that were initiated were fed by those who had the duty to put them out. He referred to the other "religions": "[...] those of the same profession are likely to be very much against us; [...] and the light of our Society offends them." ${ }^{14}$ Perhaps the image of the "guiding star" of the Jesuits was already created, so well described in the Sermon for Epiphany. Overshadowed

\footnotetext{
"Ronaldo Vainfas takes an X-ray of Father Antônio Vieira in: Antônio Vieira: jesuíta do rei, São Paulo, Companhia das Letras, 2011. He describes the profile of the Jesuit based on dense bibliography and texts by the priest himself. Among other aspects, he discusses the singular character of this Jesuit in relation not only to the great power he gained due to his proximity with the king John IV, but also to the mystery of his mulatto origin, his prophetic writings and his great talent to seduce audiences and make enemies with his sermons.

${ }^{12}$ About the Jesuits arrival to Maranhão, see: José de Morais, História da Companhia de Jesus na extinta província do Maranhão e Pará [1759], Rio de Janeiro, Editorial Alhambra, 1987, p. 78-80.

${ }^{13}$ Antônio Vieira, apud Serafim Leite, História da Companhia de Jesus no Brasil, Tomo IV, Lisboa/Rio de Janeiro: Portugália/Civilização Brasileira, 10 v., 1938-1950, p. 45.

${ }^{14} / d e m$, Ibidem, p. 46.
} 
by the powerful "light" of the Society, the other religious orders would follow different guidelines in the game of power.

Vieira retreated, strategically. The captain-major received a proposal signed by the local authorities, religious people and the State, which defended: the legitimacy of the slaves, since the entrances and rescues in the countryside were licit - because the "barbarian natives" were the "worst people in the world" and, if set free, they would be against the Portuguese. In the proposal, there was also the most important of reasons: the "republic" could no longer be sustained without the natives.

According to Vieira, this document was signed by the prelates of all of the "religions" and by two vicars. Jesuits were asked to sign the same document, but they refused to do so. There was another mutiny. This first battle of Vieira indicates the difficulties faced by the Jesuits' catechism project inside the reality of the colony. In October, 1653, the King gave in to the pressures of the residents of Maranhão, and promulgated another law that, by repealing the former one, was more favorable to the slaves. ${ }^{15}$

Back then, Vieira had already made his first entry into the countryside towards river Tocantins. With the acquired experience, he realized the problems that could arise by the use of natives as slaves, in the conversion of the pagans and, at the same time, safeguarding the interests of the Crown. The Jesuits in the villages that he administered felt difficulties because they had no power to stop the natives from retreating and going in the direction to take up the work of residents, which made Vieira's indoctrination difficult, if not impossible.

In the villages, the natives were absent due to the tasks related to tobacco, so these places were inhabited for eight or nine months a year. Besides tobacco, the natives were used for fishing, searching for cloves and herbs, producing cotton, waste, ships etc. Therefore, they were absent, at times, for two to three years. Vieira also denounced when the natives of entire villages were taken to work in mills or sugar farms belonging to the colonial authorities. Jesuits were powerless and could not prevent any Sergeant or corporal squad, ordered by the main captain-majors, to go to villages and take male and female natives. Vieira even stated that slavery was faced by these natives with 'less sorrow' than the "freedom" they had in the villages. According to him, they did that by mixing with the slaves of the Portuguese. They lived with them and married them in order to escape from their lives in the villages, when they did not go deeper into the countryside. As stated by the Jesuit:

[...]others, who had more pride and value, were lost amongst the Pagans, and with the news they received, they retreated from faith and confirmed their presence in the lives they had and with the resolution of not wanting to be subject to the Portuguese. ${ }^{16}$

15/dem, Ibidem, p. 50-51

${ }^{16}$ Antonio Vieira apud Serafim Leite, História da Companhia de Jesus no Brasil, Tomo IV, Lisboa/Rio de Janeiro: Portugália/Civilização Brasileira, 10 v., 1938-1950, p. 52. 
With this initial experience, Vieira went to the Court and took three resolutions that would enable, in his opinion, the effectiveness of conversion. They were: firstly, not to declare an offensive war against the pagans, but only to rescue the legitimate slaves from them; secondly, Christian natives and vassals could not be forced to serve longer than the time established by the law. Besides that, they could remain in freedom, being governed by their Principals ${ }^{17}$ and by the vicar in charge; thirdly, missionaries should be able to establish their missions in the countryside freely, without depending on governors, so it would be up to the person in charge of the missions to choose his destination. As aforementioned, the law of 1655 crowned his victory in the Court.

Actually, such victory did not last long. In 1661, Vieira became weak because his great ally, governor André Vidal de Negreiros, took off to Africa. Apart from this, he faced several charges made by the Chambers of both captaincies, and finally he was expelled from Maranhão and Pará. Two of the accusations against Vieira stand out. One refers to the letters he had sent to the King by the Bishop of Japan, intercepted by Carmelite members, who made them public. In these letters, the Jesuit accused the population of that State of not obeying the laws against the slavery of the natives. Another accusation referred to the fact that Vieira had got the Principal, Lopo de Souza Guarapaúba, arrested - and this charge was the most interesting one. ${ }^{18}$

The first accusation reveals the major conflicts that were established between Religious Orders. It also shows which side they chose in this game of forces. The second charge is more decisive, because it affected the Jesuits in a sensitive matter - their supposedly unconditional defense for the indigenous populations. At the same time, it reveals the complexity of the way Christian natives interpreted the relations established with the colonial European population - be them priests or laymen. In a way, Vieira does not mention, in the cited reports, that the natives themselves decided to escape from the villages to integrate with the "house" of slave owners, to become one of them - and this symptom could have been involved in the game of relations.

The imprisonment of the Principal was reported by Vieira himself, when he responded, in a letter to the King, about the charges against him. He stated that this Principal did not obey the laws of Your Majesty and, in order to do that, he was supported by the powerful men for whom he worked. What seemed to bother Vieira, however, was that the Principal and his group lived as pagans: “[...] being Christians for a long time, because, besides having many

\footnotetext{
17The word represents a type of distinction of indigenous leaderships. t.n.

${ }^{18}$ The episode of Vieira's expulsion involving the Principal Lopo has been cited by other authors. Specially: João Lúcio de Azevedo, Os Jesuitas no Grão-Pará: suas missões e a colonização [Fac-sim, ed. 1901], Belém: SECULT, 1999, p.78. More recently, it was mentioned by John Hemming, Ouro Vermelho: a conquista dos indios brasileiros, trad. Carlos Eugênio Marcondes de Moura, [1995], São Paulo: EDUSP, 2007, p. 490-491. In both cases, the authors only mention the fact without diving into the contradictions of the several versions of the event, and their work is not very different from that of Serafim Leite, which will be mentioned right after in this text. Here we use a set of documents that demonstrate other versions of the fact and describe the action of the Amerindian population in this important conflict.
} 
girlfriends the so called Principal had married in facie ecclesiae to a sister of another woman, with whom, before marriage, he publicly had children with". Vieira accused him of not following the principles of the Christian doctrine: he would not attend the mass or follow any of the sacraments. The Jesuit said that these Christian natives died without confessing, like pagans. He also accused the Principal of enslaving free natives and selling them. Finally, he stated that: "[...] he had the others killed with pagan ceremonies". For Vieira, those who should punish him did not do it "due to vile interests." ${ }^{19}$

The conflict between the interests of the Society of Jesus and those of some indigenous Principals - including the arrest of the Principal Lopo de Souza - shows only the tip of the iceberg. Indigenous populations were not indifferent to the missionaries they were in touch with: when choosing one to the detriment of others, they considered private interests. Even though the Jesuits were superior for some of them, there were also those who chose other orders. Some even preferred it when a layman was the administrator - even if that made them slaves. Therefore, it is not so simple to understand the process of administering the indigenous populations when trying to focus on their objectives - the natives, especially Christian Indians. ${ }^{20}$

The case of Lopo de Souza not only explains the conflict of interests between the Society of Jesus and the indigenous populations, but it also emphasizes the contradiction between the interests of the Jesuits, the other religious orders and the colonial authorities. In a way, this episode emphasizes the contradictions by demonstrating, in detail, the characteristics of the complex relationships that existed in the colonial universe as a result of the decisions made by the Crown or by their devoted allies at that moment: the Jesuits. Even if the interests of the Society were mixed, at times, with those of the Portuguese Crown, they went beyond. The imprisoning of this Principal can reveal much more than a conspiracy for the expulsion of the Society or vile interests against faith, as Vieira wants the others to believe, through his writing. In the documents, the voice of these natives is present and presents another version that exposes complex relations with new aspects, turning these populations into role actors in this story.

\footnotetext{
${ }^{19}$ Antonio Vieira, apud Serafim Leite, História da Companhia de Jesus no Brasil, Tomo IV, Lisboa/Rio de Janeiro: Portugália/Civilização Brasileira, 10 v. 1938-1950, p. 55-56.

${ }^{20}$ Several studies have revealed creative and innovative ideas of these populations searching for autonomy. Historian Elisa Frühauf Garcia shows how the natives in the missions of the South of Brazil, in contact and negotiating with the Portuguese, influenced the production of indigenous policies in the Portuguese Empire by means of their political agency. In: As diversas formas de ser Indio - políticas indígenas e políticas indigenistas no extremo sul da América portuguesa, Rio de Janeiro, Arquivo Nacional, 2009. For the region of the current Rio de Janeiro, the important study of Historian Maria Regina Celestino de Almeida entitled Metamorfoses Indígenas - identidade e cultura nas aldeias do Rio de Janeiro, Rio de Janeiro, Arquivo Nacional, 2003 shows the important paths, which were hidden, of the participation of Amerindian populations in the construction of colonial Rio de Janeiro, exploring the process of transformation of these populations into vassals of the Crown, including in the colonial nobility. Other studies have come up in the past few years, directed by John Manuel Monteiro, who, after the publication of the classic Negros da Terra - indios e bandeirantes na origem de São Paulo, São Paulo, Companhia das Letras, 1994, oriented new studies that insert Amerindian populations as role characters in the history of Brazil. To access these new contributions, see: www.ifch.unicamp.br/ihb/
} 


\section{A Christian Indian and enemy of Vieira}

The Principal Lopo de Souza Guarapaúba was not a young man. He should have been about 60 or 70 years old. He fought in the war to conquer back the region and, as a reward, the King gave him the 'habit of Christ.' He was already known in 1647. At the time, he signed a document promising to be loyal to the White men, represented by the donatary of the captaincy of Caeté. He and his group were invited to "go down" and promised to be baptized as Catholics. Besides, they would be paid for their work when serving in the donatary and the White residents of the Santa Tereza village. ${ }^{21}$

Together with one of his sons, he would lead, 11 years later, one of the most important villages in Pará. The Maracanã village was strategic for the region for two reasons: first of all, in its surroundings there were the salt mines of the King, which provided salt for the captaincy. This village not only brought important profits to the Royal Treasury, but also provided salt to the city of Pará. Secondly, it was a passage center that supported the boats that were going from Pará to Maranhão, and vice-versa. It helped those who were sailing in that area and provided guidance. This orientation was indispensable for boats moving between both the captaincies.

The episode of Lopo de Souza being arrested by Vieira reveals much more than the Jesuits expected, and showed the complex game of relations between the several characters involved. The version of Vieira, when compared to that of the natives in the village and the religious men of Santo Antônio, Mercês and do Carmo, about the same episode, seems to be at least partial — not to say unreal.

The repercussion of the imprisonment of the Principal of the Maracanã village was much greater than the texts of Vieira demonstrate. The episode gained visibility when the natives of the Maracanã village appealed against their Principal's arrest to the General internal affairs and major trustee of the King's treasury in the State, the licensed Diogo de Souza e Menezes. That petition arrived to the bookkeeper on April 24, 1661, together with another one from the Chamber of Pará and a letter, supposedly written by Vieira and addressed to the Principal Lopo de Souza. In the letter, according to the natives, Vieira asked the Principal to go on with father Francisco Veloso: "as a loyal and faithful vassal both of the Church and of Your Majesty, he did not hesitate or postpone it, accompanying the so called priest". Here is another piece of the natives' petition:

[...] not noticing the many conditions caused by his old age, and arriving to the city, going to school to pick up and talk to the reverend Father Antônio Vieira, and passing by the entrance with applause from those who received him, they unarmed him and took off his habit of Christ, which had been given to him by Your Majesty, they put him inside a prison cell with a chain attached to his feet, where he spent some days, and from there he was taken

21Sociedade Geográfica de Lisboa (SGL), Códice I, Res 2 - E, f. 69v - 70. 
to the Fort of Gurupá, where until now nobody has heard of what has been done to him, and until now nobody knows why this offense and injustice happened to him, since they were not caused by the service of God and Your Majesty, to whom he has always served, as well as the conquest and restoration of this state $[. . .]^{22}$

The petition goes on and demonstrates that these Christian Indians knew about their importance in the political and economic scene of the State. They argued that they always served the interests of the King and cared for the Royal salt mines, which provided salt for all of the surrounding regions. Facing this fact, they stated that the salt mines would be lost, as well as the support they had been giving to the navigation between both the captaincies belonging to the State. They also pointed out that they always provided flour, fish and meat to the infantry regiment established in the fort of the captaincy of Pará. All of these, however, would be stopped because of the absence of their Principal in the village, since all of the village's people and others, neighbors and their relatives, would be off to the woods due to the accusation that had been made against their Principal. They argued that he would not have committed any crimes against the Church of God.

The acute perception of these natives concerning the complex legal course is demonstrated when they questioned the legality of the Jesuit's attitude. They stated that, in case their Principal had actually broken any law of the Church, such crime should be judged by the General Vicar, since, in their opinion, he would be the right person to judge and pronounce the necessary punishment. On the other hand, if the crime had been committed against Your Majesty, it would be up to the governor to judge it and choose the due punishment, in case he was guilty. The natives mentioned that their Principal had never disobeyed the governor, and was always a loyal vassal to Your Majesty. Therefore, they asked the governor, out of respect for his status, to order the infantry and the Justice of Pará and Gurupá to bring their Principal to his presence, so that the governor could verify if the Principal was guilty or not, and then do whatever seemed fairer. Therefore, they said, the inconvenience to the services of God and Your Majesty would be prevented. ${ }^{23}$

After the receipt of the natives' petition and the one from the Chamber of Pará, the governor requested his internal affairs to run a diligence and gather information on the case from the people who came from Pará. In that moment, the headquarters of the State government was in São Luís do Maranhão. ${ }^{24}$ The internal affairs person, after hearing the witnesses, would give his opinion. It would not be difficult to find these people, since Maracanã was a passage route between the two captaincies, and the movement of canoes between the two cities was always busy. He heard from: Friar João das Neves, Commissioner of the religious of Santo Antônio; Friar

\footnotetext{
22Biblioteca Nacional de Lisboa (BNL), Coleção Pombalina, PBA 645, f. 525.

${ }^{23} / \mathrm{dem}$, Ibidem.

${ }^{24}$ Vieira got the unification of the State from the king, with headquarters in São Luís. Before that, captaincies had administrative autonomy.
} 
Manoel da Encarnação, Provincial vicar of the Carmelites; Friar Marcos da Natividade, Provincial vicar of the Mercedarian order; Domingos Fialho, former storekeeper of the Royal treasury of Your Majesty in the captaincy of Pará and the Resident of the captaincy; Antônio de Mattos de Sampaio and the reformed Captain Bernardo Varella de Bulhões.

After hearing the testimonies, the internal affairs made a report and the governor Pedro de Mello made another one. In this process, besides the testimonies of the witnesses, there were also two petitions from the natives and the Chamber and their respective documents, a letter that would have been written by Vieira, addressed to the native Principal Lopo de Souza.

\section{Indigenous populations were not indifferent to the missionaries they were in touch with: when choosing one to the detriment of others, they considered private interests}

Also there was a letter from the governor sent to the Jesuit, in which he reported the events that occurred in the village and exposed his report to the superior of the Jesuits.

The testimonies of all witnesses confirmed that the mentioned village was in disarray and its inhabitants had decided to leave it, in case no actions were taken to set their Principal and sergeant-major free, who had also been arrested by the Jesuits.

Friar João das Neves, Commissioner of Franciscans of Santo Antônio, stated that he was accompanied by the provincial of the Carmelites and other religious men, coming from Pará to Maranhão. He stated that they stopped by the Maracanã village to look for some items to continue the journey, and also to look for a guide. According to him, the Principal Lopo de Souza, together with his children, had "indoctrinated" the natives, who always received the White men with open arms, by assisting them when they came looking for flour and goods for their journeys. But, when he passed by there, he noticed they were different and were ready to leave the village and go off into the woods. They considered that Lopo de Souza's arrest was unfair and believed that he had been betrayed. The Commissioner tried to calm them by saying that their Principal was about to be set free. They answered that, in case he was set free, they would not leave the village. The friar also testified that the Principal, even rang the bell of the church to call his children. Afterwards, he came with his knights so the indoctrination could take place. According to the friar, this demonstrated his effort so that his natives could know God. He also believed that the salt production would be harmed because there were no other natives who could work in the salt mines like 
they did, since they had been well "indoctrinated" by their Principal. As to commerce, there would be no other village in that route that could be useful for whoever was moving between the two captaincies. ${ }^{25}$

Friar Manoel da Encarnação - provincial of the Carmelites said that when he was in the Carmo monastery, in Pará, a native called Tomé, captain of the Maracanã village, came to him and said that since Father Vieira had arrested his Principal, he came to hide in the convent. According to the information given by the native, he knew his Principal was imprisoned in Pará and was not allowed to receive any visitors. In his testimony, he also said to have seen him in the Maracanã village: "[...] I saw all of the pagans, male and female, little or big, saying [...], they wanted to retreat from the place where they lived and no longer wanted the company of the White men, as they had decided to go off into the woods [...]." ${ }^{26}$

The native captain Tomé had also gone to the Mercedarian convent, in Belém, and, according to the provincial order, Friar Marcos da Natividade, he asked the friar, together with the other prelates of the other regions, to give back his Principal, which father Antônio Vieira had imprisoned in the school. The friar asked him to look for Chamber officials. The native captain, helpless, told him he was going back to his village. The provincial took the opportunity to ask for a guide from his village, since he was on the way to Maranhão. The captain's response was strategic - he said he could not find the guide, because the natives could have gone off to the woods. Feeling obliged to do so, the friar went to the village and found it barely inhabited. So, he told the natives that he would, together with the Carmelite provincial and with the Commissioner of Santo Antônio, present to the governor D. Pedro de Mello the problems that were created due to the arrest of their Principal. ${ }^{27}$

Friar Marcos also mentions that captain João Fernandez, who had helped in the salt mines of Your Majesty, that he was "benefitted" by these natives, and stated that he would go to the captain-major and trustee-major of the Royal Treasury to ask for a solution, since the natives were no longer in the salt mines. Natives had said that, in case both of the arrested (their Principal and the sergeant) did not return, they would go off to the woods. Curiously, this captain was the son-in-law of the Principal Lopo de Souza. Another witness, named Antônio de Mattos de Sampaio, stated that the Principal Lopo de Souza was deceived by a letter received from Father Francisco Veloso, written by Father Antônio Vieira, in order to attract the Principal to Pará under false pretenses. ${ }^{28}$

The testimony of Antônio Mattos de Sampaio has other details concerning the imprisonment of the Principal. According to him, Friar Marcos informed that, when the Principal was arrested by the Jesuits, they took off his 'habit of Christ', pushed him violently and, after unarming him, they took his stick and threw it out. The symbolic aspect of this attitude was powerful. It was a real offense, which possibly made the episode much more dramatic. Antônio Mattos also mentions

\footnotetext{
${ }^{25}$ BNL, Coleção Pombalina, PBA 645, f. 527 v.

${ }^{26} / \mathrm{dem}$, Ibidem.

${ }^{27}$ Idem, Ibidem, f. 528

${ }^{28}$ BNL, Coleção Pombalina, PBA 645, f. 528v.
} 
something that might explain the real motive for the arrest of Lopo de Souza by Vieira. According to him, it all happened because the Principal did not want to agree with the temporal government of the priests of that Society in his village, except for the spiritual field. ${ }^{29}$

All of the testimonies are unanimous and confirm the decision of the natives to abandon their village. The arrest of the Principal of the natives may seem to be another conspiracy produced by the religious orders and the members of the colonial government. In contrast, the episode reveals the enlightening aspects about the type of practice these natives were able to use to achieve their interests. The natives kept the letter supposedly written by Vieira and attached it to their representation, in order to prove the trap set by the Jesuit against their Principal. Here is the transcript of the supposed letter from the missionary:

[...] I feel you are so unhealthy, but these are conditions of age, and memories that God gives you, so that you offer your soul as someone who knows there is another life, this is what I have always wished from you, and you must believe me without listening to other lies, since these ideas do not cross my mind [...] it sounds good to me that we can talk as you wish, and in case you do not possess a canoe, you can come with your Father Francisco Veloso and whoever you want to bring with you, before I leave to Gurupá [...] because in all that is fair, I should help you, every way I can: May God keep your Grace, that is my wish [...] Antônio Vieira. ${ }^{30}$

In case the letter is really from Antônio Vieira, which seems to be plausible, the trap produced by the Jesuit to arrest the Principal is clear. ${ }^{31}$ On the other hand, due to various testimonies, the statement of the Jesuit that the native Principal practiced cannibal rituals or sold natives to his partners does not seem to be real, as he tried to expose in the other letter sent to the King. It is possible that some slaves had been sold, but the importance of the salt commerce would overcome that. At the same time, even though both the religious orders and the colonial authorities were interested in discrediting the Jesuit for his attitude against the enslavement of natives, it does not appear that they were more concerned about fighting their Jesuit enemy than losing such an important location. As we have observed, this village was much more important for salt commerce, for the supplies of canoes and the infantry itself. The petition made by the Chamber of Pará clarifies how important the control of this village was to the government of the captaincy and, at the same time, the importance to keep the referred native Principal as an ally. They talk about his arrest:

[...] Lopo de Souza, from the Maracanã village, is said to have been arrested by the reverend Father Antônio Vieira, who sent him to

\footnotetext{
29/dem, Ibidem, f. 531

30/dem, Ibidem, f. 529

${ }^{31}$ The document is a recovery made in the $18^{\text {th }}$ century from another text written at the same time as the original document. These documents were verified by all of the authorities who saw them, and, more importantly, by governor Pedro de Mello. At the same time, all of these documents were sent to the Jesuit, who, after possessing them, could have denied authorship and stated the letter was false in the mail sent to the king, in which he tells what happened - which he did not do.
} 
Gurupá, which resulted in a major scandal for the people in this State, especially to the natives, and for now the native Principal is a great server of Your Majesty, and for being located in a region of passage for those who sail from this city to Pará, and for producing the salt of Your Majesty, so that population is very important, increasing the treasury of Your Majesty, ordinarily the infantry uses the supplies from the village, and his arrest could lead to great ruin [...] so we claim Your Excellency [...] to be informed on the case and bring the native in order for his justice to be revised, Your Excellency shall act as we all expect $[. . .]^{32}$

The tense situation, which was created at the time when Vieira was expelled, marks the first stage of the relations between the religious orders, the colonial authorities and the Christian natives in the beginning of the second half of the $17^{\text {th }}$ century. In the texts by Vieira, there are many ideas connected to a conspiracy against the orders of the King and the Christian interests, which the Jesuit's "guiding stars" were most skilled to defend. Taking a closer look, however, things get complicated. The game of interests was very complex. The documents on the episode involving the arrest of the old Principal reveal a set of strategies that the Indians, who had already been baptized as Christians, used to protect their interests, even if their autonomy was minor. Even so, they had some bargaining power. The argument of leaving the village and the awareness of their importance for the communication between captaincies, and for being the suppliers of the salt that was offered to the external market shows their refined political strategy, without a doubt. On the other hand, the role played by Vieira in the episode demonstrates the other aspects, which were no less important, to understand the game of power that the Society played at that time.

The most important reason was among the ones Vieira presented to the King. Maracanã village, which already existed before the Jesuit arrived, and was destined to be under the Royal control, was administered by a Principal, old ally of the Crown who possessed the 'habit of Christ'. This same Principal refused to be administered in the temporal administration by the missionaries of Society of Jesus. This was certainly an offense to the interests of the institution, and, even worse, to the interests of the missions' superior and friend of the King, Father Antônio Vieira. Lopo de Souza, throughout the years in which he was the Principal of his people, established friendly relationships with the Portuguese, and these should clearly show mutual respect and interest. He was strategically well-positioned in the game of power relations in the region. Vieira interfered in this game of power in a way that seemed to be wrong. The Jesuit misjudged the consequences of his attitude. He created a real problem for the salt supply, for the commerce and communications between both the captaincies.

The report of the internal affairs is pretty clear as to what should be done in that case. It states that the Principal Lopo de Souza was very careful in relation to the services of Your Majesty, and was very useful for his treasury. Besides, he was in charge of the salt mines that assisted the entire region, including the city of Pará, without any costs for the Royal Treasury. At the same time, he played an

32BNL, Coleção Pombalina, PBA 645, f. 529-529 v. 
essential role in the village, providing the canoes that passed by from one captaincy to another providing them with rest and supplies. In his opinion, the arrest of the Principal caused two main losses: the salt mines and the loss of "our holy catholic faith, which the passion of Father Antônio Vieira did not care to fix". It would also lead to massive losses to the Treasury of Your Majesty. He concludes by saying that, since natives were very determined, in case their Principal did not return to the village, they would go off to the woods and everything would be lost and abandoned. Therefore, it was important that the governor should set the Principal Lopo de Souza free, and that he was taken to his village immediately. And, in case he was guilty, this fact would be verified, and, according to the law, he would be punished. But he emphasizes: "[...] without the hate created from ambitions." 33

Part of historiography states that governor Pedro de Mello, old ally of Vieira, was a traitor of the Jesuit cause. This historiography is based on Jesuit reports, including the ones by Vieira himself and José de Morais. These are overstatements. Another possibility is that the governor was in a delicate situation being Vieira's ally, and at the same time, he was the governor of the State, which made him the representative of the King, but also a defender of the interests of his inhabitants. His position is clear when he makes the decision on the case of Lopo de Souza.

\section{In case the letter is really from Antônio Vieira, which seems to be plausible, the trap produced by the Jesuit to arrest the Principal is clear}

Carefully, the governor defined his opinion. He did not listen to the report of the internal affairs person. He ordered that the arrested Principal Lopo de Souza be brought to the fort of Pará and asked Father Antônio Vieira to apologize, so he could be punished. He reinforces the request to Antônio Vieira. In the document, he lets something pass: "[...] will send a canoe with the people you choose, with my order I mean my petition, and I do not mean an order to Father Antônio Vieira to give me the so called Principal". ${ }^{34}$ While transmitting his report, he also wrote a letter to the Jesuit. Almost begging, he wrote:

[...] to ask Your Paternity, with all my heart, that Your Paternity can deliver me the arrested Principal of the Maracanã village Lopo de Souza in the fort of this city due to the reasons and protests, which [...] your Paternity will see by the exchange of papers that go along with this one, that he will be punished by whoever is in charge, and this is my intention, and no longer avoid the damage that otherwise can take place, giving him the punishment he deserves [...] I ask you again, your Paternity, in order to prevent what I herein report $[\ldots]^{35}$

${ }^{33}$ BNL, Coleção Pombalina, PBA 645, f. 533.

${ }^{34} \mathrm{BNL}$, Coleção Pombalina, PBA645, f. 534 (pointed out by me).

35/dem, Ibidem. 
This episode presents the complex game of powers and political architecture that was present in the Amazon region. In it, the role of the Christian Indians was not small. After all, those who confronted the powers of the Jesuits' superiority more, before the authorities, prelates of other regions and the Chamber itself, were these "determined" natives.

\section{Final considerations}

The Jesuit's speech, evidenced by historiography, which is sympathetic and pleads the missionary's mercy, is in contrast with others, which reveal different voices. Such voices, despite being reproduced by the power, were brought about by another "invention" of facts. In the text by Vieira, the contradiction between the idea of freedom, preached by the missionary, and that of Christian Indians choosing to search for the house of some owner and becoming slaves by their choice and abandoning the mission, stands out. Unaware of how to defend their souls, the Christian Indians were worried about defending their bodies. The freedom imposed over them by the Western rulers was far worse from the loose and broad movement allowed by their ancestors' habits. Before being free in missionary villages, they could wander around, across the rivers, hunting, fishing, sleeping with their relatives in wall-less huts, or exercising their sexual and marital practice without the disturbing interferences from the moralistic Christian speeches. Many times, in their limited maneuvering margin, they took control of their destinies and chose slavery instead of this narrow freedom offered by the missionaries. After all, the slaves of the colonists were contradictorily freer.

In the mission, space was controlled, and the domain was deeper being prolonged from the body of the mission to the body of the natives. Gestures, ways of walking, talking, living and relating went through changes and restraints.

Therefore, Lopo de Souza could not give in to the intentions of Vieira to take over the temporal government of his village with the Society. He dealt with the colonial administration and with the other religious orders to avoid it. Vieira accused the Principal of having behaviors that were inadequate to Christian Faith, but Lopo knew the rules of the game: he rang the bells, indoctrinated his vassals for the harvest and preparation of salt, accepted the Christian rituals, and provided help with rowing and provided guidance for the travelers. ${ }^{36}$

\footnotetext{
${ }^{36}$ About the relativity of this spiritual domain, see: Ronaldo Vainfas, A heresia dos indios - Catolicismo e Rebeldia no Brasil colonial, São Paulo, Companhia das Letras, 1995. About rituals thought as heresy in the $18^{\text {th }}$ century in Portuguese Amazon, see: Carvalho Júnior, "Visão do Diabo - crenças e rituais ameríndios sob a ótica dos jesuítas na Amazônia Colonial - séculos 17 e 18", PPGAS, Amazônia e outros temas: coleção de textos antropológicos, Manaus, EDUA, 2010, p. 159-194; and "A magia do novo - índios cristãos nas fronteiras da Amazônia Colonial", Nuevo Mundo - Mundos Nuevos, Debates - EHESS, 2011. Available from: $<$ http://nuevomundo.revues.org/62258>. Acessed on: 08/10/2013
} 
Antônio Vieira was depicted by Jesuit historiography as a restless defender of the Amazon indigenous populations. However, he did not defend these populations; he defended only the salvation of their souls. ${ }^{37}$ He thought that the bodies should fulfill the demand of the work in the villages and Christian moral discipline.

The powerful friend of the King, known for his ferocious rhetoric in several European courts, feared and respected by his enemies, was defeated by the native Principal Lopo de Souza. The old native knew how to escape the traps of the great orator. In the game of political actions, in the narrow place of his minor autonomy, he won the war and defended his singular freedom.

\footnotetext{
${ }^{37}$ About the idea of self-salvation through the salvation of others, see: Charlotte Castelnau-l'estoile,. "Salvar-se. salvando os outros: O padre António Vieira, missionário no Maranhão”, In: Oceanos, n. 30/31, Lisboa: Comissão N. para a Comemoração dos Descobrimentos Portugueses, abril/setembro, 1997, p. 55-64
} 